\title{
THINK-PAIR-SHARE: ITS IMPLEMENTATION TO IMPROVE STUDENTS' CAPABILITY ON UNDERSTANDING GRAMMAR ON THE SECOND SEMESTER STUDENTS OF STKIP SILIWANGI
}

\author{
Ningtyas Orilina Argawati \\ tyas.orilina@yahoo.com \\ STKIP Siliwangi
}

\begin{abstract}
Learning English as foreign language is considered difficult because it has its own systems and aspects that completely different from our mother tongue, such as the grammar, pronunciation, vocabulary, and cultural background of the language. Vocabuary is an important skill since we can not deliver meaning without words. However, learning English is not dealing only on vocabulary but also on grammar. Learning grammar becomes important since grammar can determine meaning of sentences. In the level of University students, it is quite difficult to make the students master all of the theme on grammar in one semester. Moreover, if it comes to conditional sentences. This topic really relays on the understanding of concepts. Once the students catch the concept, they will be able to solve some problems relate with the topic easily. To build their capability on understanding a concept of such a topic, teacher needs to figure out the appropriate way. Thinkpair-share seems to be a good way to teach conditional sentences. The method used in conducting this research is Classroom Action Research. The research was conducted on two cycles with total meetings were seven; three meetings were for tests, and four meetings were for treatment. Each cycle covered the step of planning, acting, observing, and reflecting. From the data collected by the researcher, it can be concluded that the capability on understanding grammar of the second semester students of university level was improved. The improvements cover two points, they are: (1) improvement on their mean score. Mean score of pre-test was 4.1875 , mean score of post-test 1 was 5.9625, while mean score of post-test 2 was 7.225. (2) improvement of their attitude and behaviour. It can be seen from their improvement of their activeness, enjoyment, curiousity and knowledge.

Key words: CAR, Grammar, Think-Pair-Share
\end{abstract}

\section{Introduction}

Learning English as foreign language is considered difficult because it has its own systems and aspects that completely different from our mother tongue, such as the grammar, pronunciation, vocabulary, and cultural background of the language. As a communication tool, language has become an important aspect of life. By using language, we can communicate with others. Parents teach us with mother tongue as our first language. Then at school, we learn second language, Bahasa Indonesia, our national language. In the development of our curriculum, our goverment decided to put English as a subject in every level. English must be taught in formal school since in the early stage.

To master English, a language learner should know about both vocabulary and grammar. Those two skills come together as a basic knowledge for students. Vocabuary is an important skill since we can not deliver meaning without words. However, learning 
English is not dealing only on vocabulary but also on grammar. Lock (1997: 1) argues that grammar is a set of rules which specify all the possible grammatical structures of the language including two aspects. They are the arrangement of words and the internal structure of word. Many teachers consider that grammar do less role on mastering English. In fact, learning grammar becomes important since grammar can determine meaning of sentences. In KTSP (School Based Curriculum of Indonesia), grammar is one of essential language elements taught to support the mastery of four skills namely listening, reading, speaking and writing (Isnaini, 2014: 1).

There are many kinds of grammar themes stated in the syllabus. Some of them are tenses, passive voice, sentences, parts of speech, conditional sentences, and many more. In the level of University students, it is quite difficult to make the students master all of that theme in one semester. Moreover, if it comes to conditional sentences. This topic really relays on the understanding of concepts. Once the students catch the concept, they will be able to solve some problems relate with the topic easily. Unfortunately, many students still use 'memorizing' technique on learning conditional sentences.

In result, they can solve the problem only when they do it together with the teacher. Then, when the teacher change the problem even a single part of speech, they will be confused and do it wrong. That is because they do not understand the concept. To build their capability on understanding a concept of such a topic, teacher needs to figure out the appropriate way. Think-pair-share seems to be a good way to teach conditional sentences.

Think-Pair-Share is a strategy designed to provide students with "food for thought" on a given topics enabling them to formulate individual ideas and share these ideas with another student. Lyman (2008: 2) states that this method (TPS) is a "multi-mode" strategy developed to encourage students' participation in the classroom activities. The students will work in pair to find out the concept without any help from teacher. They will work together and create a lot possibility of thinking. And in the end, it will develop their way of thinking. This research was conducted to describe an improvement of students' capability on understanding grammar, especially Conditional sentences, with using Think-pair-share. This technique was applied to the second semester students on grammar subject. 


\section{Literature Review}

There are two variables involved in this research; independent and dependent variable. The independent variable is the method used, think-pair-share, which influences the dependent variable; it is grammar. Grammar has wide range of topics in the syllabus on university level and this research focuses on conditional sentences. Brown (1994: 347) stated that grammar is a system of rule governing the conventional arrangement and relationship of words in a sentence. In addition, Harmer (1998: 1) suggests that grammar is the way in which words change themselves and group together to make sentences. Moreover, Grammar is a set of formal patterns in which the words are arranged in order to convey larger meaning (River, 1987: 15). In conclussion, grammar is a rule of language which has conventional arrangement to maka sentences and convey larger meaning.

The second variable to discuss is the method used to teach grammar, it is think-pairshare. Think-Pair-Share is a strategy designed and developed by Frank Lyman (1981) and associates to encourage student classroom participation. Argawati (2014: 61) defines TPS or thinking in pair as one type of cooperative learning designed to influence the pattern of students' interaction. Think-Pair-Share helps students develop conceptual understanding of a topic because they discuss it with their friend in pair. It makes them feel free to talk about everything they want deal with the topic. By doing that activity their ability to filter information, speak up conclusion and consider point of view will be developed.

Think-Pair-Share gives them opportunity not only to improve their understanding on topic, but also to build their social relation with other students during the activity. As stated by Ornstein, dividing students into small group seems to provide an opportunity for students to become more actively engaged in learning and for teacher to monitor students' progress better. It can also enhance students' cooperation and social skills (2000:311).

There are three steps of Think-Pair-Share according to Argawati (2014: 26), they are: (1) Think; the teacher gives a question, prompt, or observation related to the topic choosen, (2) Pair; teacher sets the students into pair. Then with their partner, they discuss the topic, idea or answer to develop their understanding, (3) Share; after students discuss their reasoning in pairs for a few moments the teacher calls for pairs to share their thinking with the rest of the class. 


\section{Research Methodology}

The method used in conducting this research is Classroom Action Research. Burns (2010: 2) suggests that action research is part of abroad movement that has been going on in education generally for some time and related to the ideas of "reflective practice" and "the teacher as researcher".

In addition, Gregory, Kemmis and McTaggart (in Richard and Rodger, 2001:12) says that action research is used to refer to teacher initiated classroom investigation which seek to increase the teacher's understanding of classroom teaching and learning, and to bring about change in classroom practices. While Bogdan and Biklen (in Burns, 1999:30) states that action research is the systematic collection of information that is designed to bring about social change.

The research brought into two cycles which each cycle contained pre-test and posttest. The subject study was the second semester students of university level which consisted of 40 students. There were total seven meetings covered on those two cycles; three meetings were for tests, and the other four meetings were for doing treatment. The treatment was teaching grammar, especially conditional sentences, with the application of Think-pair-share method.

The instruments used in this research were observation, interview, field notes and tests. The tests were used to test the students on pre-test, post-test 1 and post-test 2 . The tests given consisted of 20 items in the form of fill in the blank questions.

\section{Result and Discussion}

The research carried on the second semester students of university level for seven meetings. The seven meetings were categorized into two cycles. The result of each cycle will be organized on four steps of CAR, namely: (1) planning, (2) acting, (3) Observing, and (4) reflecting.

Cycle I. On planning section, the researcher prepared some lesson plans to teach conditional sentences. Lesson plans were made to be implemented on treatment 1 and 2, which contained some prosedures of Think-pair-share to teach conditional sentences. Come to the next step, it is acting. In this step, the researcher came to the class four times. The first 
meeting was used for conducting pre-test which consisted of 20 items taken from Azar (1992) and Murphy (1994). The same thing went to the fouth meeting which was used for conducting post-test which consisted of the same number as pre-test. The third step on CAR is observing. It was done together with the second step. During the four meeting, the researcher provided some field notes to capture what the students do in order to ease the process of observing them. The steps of acting and observing are displayed on table 1 below:

Table 1.

Meetings in cycle I

\begin{tabular}{|c|c|c|}
\hline & Acting & Observing \\
\hline $\begin{array}{c}\text { Meeting } \\
1\end{array}$ & $\begin{array}{l}\text { Topic } \\
\text { Pre-test: } \\
\text { Conditional sentences } \\
\text { type } 1,2 \text {, and } 3\end{array}$ & $\begin{array}{l}\text { Activity } \\
\text { In this first meeting, the researcher gave them pre- } \\
\text { test which consisted of } 20 \text { items }\end{array}$ \\
\hline 2 & $\begin{array}{l}\text { Treatment } 1 \text { : } \\
\text { Conditional sentences } \\
\text { type } 1 \text { and } 2\end{array}$ & $\begin{array}{l}\text { The students started to learn about the material in } \\
\text { pair. They discuss about the formula first with their } \\
\text { partner by arranging some words into correct order. } \\
\text { Then, they discussed some questions allowed. }\end{array}$ \\
\hline 3 & $\begin{array}{l}\text { Treatment 2: } \\
\text { Conditional } \\
\text { type } 3\end{array}$ & $\begin{array}{l}\text { They did the same as the previous meeting in this } \\
\text { treatment. The difference was only the type of } \\
\text { conditional sentences. They tried to solve the } \\
\text { problem and understand the concept with their } \\
\text { partner }\end{array}$ \\
\hline 4 & $\begin{array}{l}\text { Post-test: } \\
\text { Conditional sentences } \\
\text { type } 1,2 \text {, and } 3\end{array}$ & $\begin{array}{l}\text { In this meeting, the researcher conducted a post-test } \\
\text { which consisted of } 20 \text { items. The questions presented } \\
\text { were in the same form and level of difficulty with the } \\
\text { pre-test. }\end{array}$ \\
\hline
\end{tabular}

The last session for cycle I was reflecting. In this step, the researcher made some implication from the result of observation found during the teaching and learning process. It started from the pre-test. The students confessed that the assistance of test was surprising 
since they knew very little about the material to be delivered. However, their willingness to do test still existed. The test was conducted well even though there were some students who did really bad. The mean score of pre-test was only 4.1875. This score was considered low still the minimum score to pass the grade is 6.0. Besides, the low capability on the students was due the ability of them to understand the concept.

Most of the students had already been taught about this topic, but almost the students still missed in concept. During the treatment, 1 and 2, the researcher paid attention on the way the students worked in pairs. On the first treatment, the students looked confused. They did not know for sure what to do. They still needed the teacher's guide to do almost everything in every step. The students still felt inconvenience on working in pair. They still lost when the teacher asked them to find a formula of conditional sentences type 1 . And it came more difficult when they were asked to continue to type 2. On top of that, they created noise and disturbance during the lesson.

However, in the end of treatment 2, the researcher noticed that the enjoyment of working started to arise. They started to ask questions. It followed with the increasement of their score of post-test which hit the poin of 5.9625. From these treatment in cycle 1, we can draw conclusion that there are positive and negative result found during the lesson. The positive result is that the students begin to show their curiousity through asking question, and the negative result is the noise and disturbance from they discussed the material. The revision should be done to improve their quality of learning and also their mean of score. Therefore, cycle II was carried to continue the research.

Cycle II. This cycle only covered four steps as stated in cycle I. In planning session, the researcher made some revision towards the lesson plans. On the previous treatment, noise and disturbance still occured during the teaching and learning process. For the revision, the researcher made different partner for each student. Then, she made the students worked in pair with more tasks. They were prepared with puzzle and work sheet so that they would be busier. This strategy was hoped to reduce noise and disturbance. The acting session covered three meeting, since the pre-test used for this cycle was taken from the post-test from previous cycle as seen on table 2 below:

Table 2 . 
Meetings in cycle II

\begin{tabular}{|c|c|c|}
\hline & Acting & Observing \\
\hline $\begin{array}{c}\text { Meeting } \\
5\end{array}$ & $\begin{array}{l}\text { Topic } \\
\text { Treatment } 3 \text { : } \\
\text { Conditional } \\
\text { type } 1 \text { and } 2\end{array}$ & $\begin{array}{l}\text { Activity } \\
\text { the lesson did not hit the satisfaction yet so that the } \\
\text { researcher continued to deepen the students' } \\
\text { understanding using the revised plan. The researcher } \\
\text { provided their discussion with puzzle of words to } \\
\text { arrange formula, and a work sheet which contained } \\
\text { six problems to solve. }\end{array}$ \\
\hline 6 & $\begin{array}{l}\text { Treatment 4: } \\
\text { Conditional } \\
\text { type } 3\end{array}$ & $\begin{array}{l}\text { On this treatment, students seemed to ask more } \\
\text { questions related with the topic. In every step of } \\
\text { learning, noise and disturbance were less occured } \\
\text { since they were very busy with the task given. }\end{array}$ \\
\hline 7 & $\begin{array}{l}\text { Post-test: } \\
\text { Conditional sentences } \\
\text { type } 1,2 \text {, and } 3\end{array}$ & $\begin{array}{l}\text { In this meeting, the researcher conducted a post-test } \\
\text { which consisted of } 20 \text { items. The questions } \\
\text { presented were in the same form and level of } \\
\text { difficulty with the pre-test. }\end{array}$ \\
\hline
\end{tabular}

Reflecting of the observation done would be discussed in this section. There were much improvement in every meeting. The improvement were as follows: (1) their score on post-test 2 was increased. From 4.1875 for pre-test, it was improved to be 5.9625. and for the post-test 2 , their score became 7.225, and (2) their quality of learning shown from their attitude and behaviour during joining the lesson.

The detail result of score of the test can be seen on table 3 below.

Table 3.

Improvement on students' score of the tests

\begin{tabular}{cccc}
\hline & Pre-test & Post-test 1 & Post-test 2 \\
\hline Minimum score & 3 & 4 & 6.5 \\
Maximal score & 6 & 7 & 9 \\
Mean score & 4.1875 & 5.9625 & 7.225 \\
\hline
\end{tabular}


While the improvements on attitude and behaviour are presented in table 4 below:

Table 4

Improvement on attitude and behaviour

\begin{tabular}{lll}
\hline Points & Former condition & Improvements \\
\hline Activeness & On the first meeting, students really & the students created more movement \\
& difficut to tell. They just kept silent & during lesson. The movement created \\
and sit quitely on their desk when & when they discussed with the partner, \\
& the researcher explained the topic. & or when they tried to compare their \\
& Even, several students seemed do & result to others. They asked more \\
& nothing with their books or notes. & questions, and produced more notes.
\end{tabular}

Enjoyment The students looked so calm. But They seemed more joyful during the their condition made them more lesson. It can be detected from their difficut to tell. So much hesitation smiley face, and so much jokes when occured during the lesson. When they worked in pair. Sometimes, they they were set into pair, they looked did the task together with other pairs. uncomfortable. It could be seen from It created much enjoyment on joining their expressions; they produced the lesson. Until the last session of the little smile, they did litle work. lesson, the students still felt so energetic. It means that the enjoy the lesson more than before.

Curiousity Inactiveness becomes one of the Their mood was changed. And it indicators of low curiousity. They affected their curiousity towards the just received what their teacher gave topic given. They asked more them without any questions a long questions, they share more the explanation. information, and they laughed louder.

Knowledge The main purpose using Think-pair- In pair, transfering idea and share is to deepen their knowledge were occured very often, understanding on concept of since they work together on the same conditional sentences. The students' problem. They do take-and-give knowledge related to the topic was activity covering vocabulary, 
really bad, since the learnt about the topic on senior high school, so that not many students could recall the memory well. understanding, application, and so on. In the end, they could use their knowledge to do the test and improved their score.

This research began with aiming on the effort of improving the capability on understanding grammar, especially on topic Conditional sentences, using Think-pair-share method. Through two cycles, three tests and four treatment, the process of teaching and learning were carried out and run so well on the second semester students of university level. As it is shown on the data above that the improvement of score has reached the target which is 6.0, while the improvement of attitude and behaviour has reached the researcher's satisfaction. Therefore, the research will not be continued to cycle III. The use of this method truely can improve the students capability on understanding grammar quantitatively, through the improvement of score, and qualitatively, through the improvement of attitude and behaviour.

As stated before, Think-Pair-Share helps students develop conceptual understanding of a topic because they discuss it with their friend in pair. It makes them feel free to talk about everything they want dealing with the topic. By doing that activity their ability to filter information, speak up conclusion and consider point of view are developed. Besides, setting the students in pair gives more opportunities to the students on exploring themselves.

They encourage to share something deeper and more detail. The more they share and talk about something, the more they build their understanding on the material delivered. Think-Pair-Share gives them opportunity not only to improve their understanding related to the theme of conditional sentences, but also to build their social relation with other students during the activity. As stated by Ornstein, dividing students into small group seems to provide an opportunity for students to become more actively engaged in learning and for teacher to monitor students' progress better. It can also enhance students' cooperation and social skills (2000:311).

\section{Conclusion and Suggestion}


The research was conducted on two cycles with total meetings were seven; three meetings were for tests, and four meetings were for treatment. Each cycle covered the step of planning, acting, observing, and reflecting. From the data collected by the researcher, it can be concluded that the capability on understanding grammar of the second semester students of university level was improved. The improvements cover two points, they are: (1) improvement on their mean score. Mean score of pre-test was 4.1875, mean score of posttest 1 was 5.9625, while mean score of post-test 2 was 7.225. (2) improvement of their attitude and behaviour. It can be seen from their improvement of their activeness, enjoyment, curiousity and knowledge.

Finally, some suggestion from the researcher can be drawn. In teaching grammar, especially conditional sentences, teachers need to try many methods to improve the students' ability and understanding. One of the good methods to improve the understanding of grammar is Think-Pair-Share. To make Think-Pair-Share working properly, it needs to be applied appropriately in the teaching and learning process. The procedures of Think-PairShare are think, pair and share. It is strongly recommended for the teachers to teach grammar. Rather than using monotonous method, this method can be used as refreshment for the students so that the boredom during the speaking lesson can be decreased.

\section{References}

Argawati, Ningtyas O. 2014. The Effectiveness of Think-Pair-Share to Teach Speaking to The Second Grade Students of SMA N 01 Kartasura Viewed From The Students' Risk-Taking. Retrieved from Digital library UNS, Surakarta.

Azar, Betty Schrampfer. 1992. Fundamentals of English Grammar: Second Edition. New Jersey: Prentice Hall.

Brown, Douglas. 1994. Teaching by Principles, an Interactive Approach to Language Pedagogy. New Jersey: Prentice-Hall Inc.

Burns, A. (1999). Colaborative action research for English language teacher. Cambridge:Cambridge University Press.

Burns, Anne. 2010. Doing Action Research in English Language Teaching. New York: Routledge. 
Harmer, Jeremy. 1998. The Practice of English Language Teaching. London: Longman.

Isnaini, Eris. 2014. The Effectiveness Of Inquiry Based Teaching To Teach Grammar Viewed From Students' Risk-Taking. Retrieved from Digital library UNS, Surakarta.

Lock, G. 1997. Functional English Grammar: an Introduction for Second Language Teachers. Cambridge: Cambridge University Press.

Lyman, Frank. 2008. Description of Exemplary Techniques and Methods. London: Prentice Hall.

Murphy, Raymond. 1994. English Grammar in Use: Second Edition. London: Cambridge University Press

Richards, J. C. \& Rodgers, T. S. (2001). Approaches and Methods in Language Teaching. Cambridge: Cambridge University Press.

Rivers, Wilga M. 1987. Interactive Language Teaching. Cambridge: Cambridge University Press.

Ornstein, Allan C and Lasley, Thomas J. 2000. Strategies for Effective Teaching. New York: McGraw-Hill. 